\title{
Tax Shelters - Sound Strategy Or Dangerous Game?
}

Paul Masar, (Email: paul.masar@gt.com), Grant Thornton LLP, Colorado Springs

Scott Butterfield, (Email: sbutterf@uccs.edu), University of Colorado at Colorado Springs

\begin{abstract}
Tax shelters, once thought to be extinct due to the at-risk and passive activity loss rules, continue to appeal to corporations and wealthy individuals. While some legal activities such as owning your own business, home ownership, retirement plans, and like-kind or section 1031 exchanges may allow you to "shelter" income, some individuals and organizations continue to invest in schemes that the Internal Revenue Service finds unacceptable. Known as abusive tax shelters, the IRS issued a new set of regulations on February 28, 2003 in an attempt to identify these transactions, and ultimately, end their use by taxpayers. This article provides an overview of tax shelters, highlights some of the more famous tax shelter scandals, and provides guidance on the rules surrounding the use of tax shelters.
\end{abstract}

\section{INTRODUCTION}

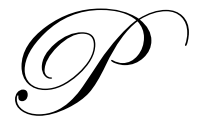

rior to the Tax Reform Act of 1986, tax shelters were a popular way for taxpayers, especially individuals, to minimize or avoid paying taxes altogether. This legislation eliminated many players. Because of these changes in the law, the focus of tax shelter activity moved to the corporate arena, where the passive loss rules do not apply and the tax law is more complex. As a result, tax shelters have again come under intense scrutiny by the Internal Revenue Service (IRS) over the past year. Moreover, even though tax shelters have tight restrictions on their use, some taxpayers have come up with creative ways to avoid paying taxes. Because of this activity, the Internal Revenue Service has recently begun moving aggressively to combat abusive tax avoidance transactions. This paper will review the background of tax shelters and how they worked. It will also review the current regulations released February 28, 2003, recent IRS enforcement, and some of the ways that people and corporations make use of tax shelters today.

\section{HISTORICAL BACKGROUND}

In the past, tax shelters were popular investments for tax avoidance purposes because a taxpayer could use the losses or deductions to offset income from other sources (Hoffman, Smith, Willis, 2003). Throughout the 1970's and 1980 's, tax shelter promoters promised deductions and credits that often exceeded the amount of a participant's investment. These deductions and credits usually relied upon inflated valuations, non-existent activities, and properties (Williams, 2003). In many cases, the promoter not only misrepresented the tax benefits available, but also misrepresented the nature of the investment entirely. These investments especially benefited taxpayers in higher income brackets. They offered investors the opportunity to buy deductions in ventures that were never expected to make a profit.

During the Seventies and Eighties, many thousands of individuals invested relatively small amounts per person in tax shelters promoted by small promoters, boutique law, and accounting firms. While the total tax dollars at issue were very large, the tax dollars at issue per taxpayer were relatively small. In the 1990's, participation in tax shelters shifted to corporations, corporate executives, and high net worth individuals. Major law firms, accounting firms, investment banking firms, and other financial institutions marketed these abusive tax avoidance transactions. In a GAO report issued in February of 2005, the IRS estimates total losses from tax shelters between 1998 and 2003 at $\$ 128.9$ billion (See Figure 1). 


\section{Figure 1}

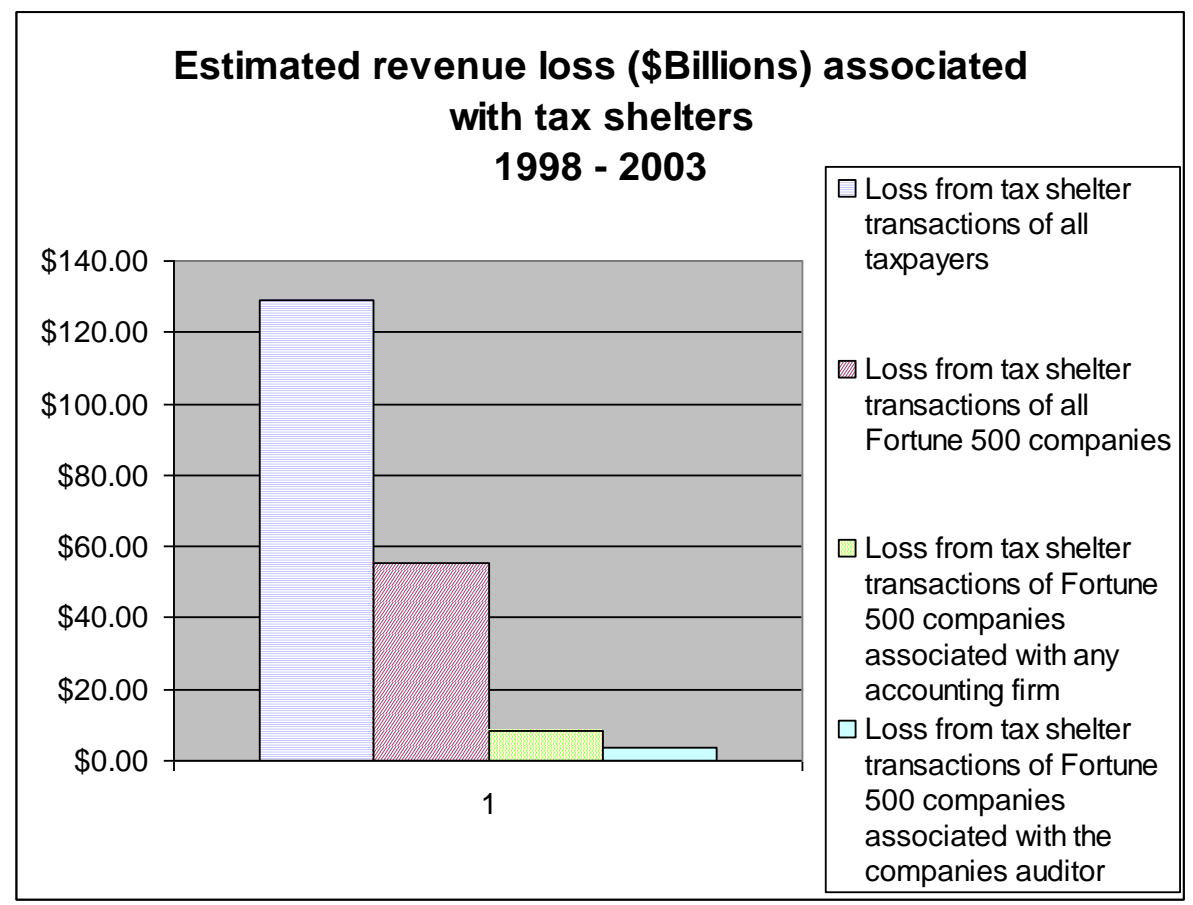

In 1973, the IRS's initial shelter program focused on four areas: oil and gas, real estate, movies, and farming. During the next ten years, 325,000 shelters came under investigation with almost 18,000 cases being docketed. Congress' first substantive response was the Tax Reform Act of 1976, which enacted the "at-risk" rules limiting individuals from claiming losses for certain investments for which they had limited economic risk.

The Deficit Reduction Act of 1984 also contained numerous provisions aimed at tax shelters. For the first time, it became necessary to register tax shelters with the IRS. Registration of tax shelters was designed to help the IRS locate and evaluate tax shelters. Organizers and sellers of "potentially abusive tax shelters" also were required to maintain a list of investors in registered shelters.

Key players in the tax shelter trade included accounting firms, investment banks, law firms, and, of course, the willing individual or company. Initially, accounting firms sold most shelters. In the late Eighties, investment banks entered the game. They had big advantages over accountants, that is, the ability to sell securities and raise capital. Hiring away the smartest tax minds in the business, Wall Street started marketing sophisticated new products. These deals enabled companies to generate large capital losses on paper to offset large capital gains.

Law firms were the other key player in the game. Occasionally, partners would come up with new ideas and market them to accounting firms or banks. But primarily they wrote opinion letters vouching for the legality of tax shelter deals. Under IRS rules, these legal memorandums constituted evidence of good faith, immunizing companies from penalties for disallowed tax shelters (France, 2003).

In the Eighties, Congress reacted and passed the Tax Reform Act of 1986. However, new forms of tax shelters got around the 1986 bill. In 1995, Enron entered into its first deal in a shelter widely promoted by Arthur Andersen. The deal nearly fell through because of pending Congressional legislation that would require the potential registration of that tax shelter. Salvation came in the form of the Washington law firm of Akin, Gump, Strauss, Hauer $\&$ Feld, LLP. They wrote an opinion letter vouching for the legality of the transaction. Finally, in 
1997, in an attempt to combat these new shelters, Congress passed a law requiring confidential corporate shelters to be registered, "a measure that is widely ignored" (France 2003).

Legislation has eliminated or reduced the effectiveness of tax shelters for many, which allowed taxpayers to offset losses from certain investments against income. Because of this legislation, individuals can deduct losses to the extent of their economic investment (at risk limits) and must classify losses into one of three categories, active, portfolio, or passive. Losses or expenses generated from passive activities can only be offset against income from other passive activities. Any excess is suspended and carried forward to offset future passive income or when the activity is disposed of. At that time, suspended losses can be offset against active and portfolio income as well (Hoffman, Smith, Willis, 2003).

\section{Project Steele}

This deal between Enron and Bankers Trust involved a pool of mortgage-backed securities that had lost money. These securities, owned by Bankers Trust (BT), could therefore be cashed in for tax deductions. BT transferred the securities to a new partnership jointly owned with Enron. Enron, for its part, added some assets of its own such as cash and airplane leases. The completed transactions allowed both BT and Enron rights to the deductions.

Under the Internal Revenue Code, this would normally be illegal. The code prohibits one company (Enron) from buying another organization simply to acquire its deductions. To get around this, Enron claimed that it had a legitimate business purpose for the transaction other than tax avoidance, that is, to "inflate earnings." Or, as Akin, Gump stated in their opinion letter, "to obtain financial income" (France, 2003). All the firms that helped Enron to build its tax shelters defend their actions, but the Senate Joint Committee on Taxation has attacked the deals. The professionals who created these schemes point out that companies have a legitimate right to minimize their tax bills, the law is unclear, and not all shelters are illegal.

\section{Long-Term Capital}

Long-Term Capital officially organized in the Cayman Islands as an unregulated investment pool. By law, it was open to only the very wealthy. Long-Term Capital ended up collapsing in 1998. This fall concerned the Federal Reserve to the point that it established a bailout fund to avert what it feared would become a worldwide financial panic.

Now in the early stages of a trial, the outcome will determine if Nobel Prize winner, Myron Scholes, and his partners must pay $\$ 40$ million in taxes and $\$ 16$ million in penalties and interest. For ordinary Americans, the lesson shows how the rich can mine the tax code in ways not available to others (Johnston, 2003).

The concept Scholes brought to Long-Term Capital involved making money in the securities markets by applying a technique for valuing stock market options that he helped invent. Known as the Black-Scholes method, it has become the standard for option traders.

Long Term Capital became an instant success with the returns from 1994 to 1996 ranging between 28.1 and 58.8 percent. That very success also created a huge tax bill. The tax shelter solution came in the form of stock in companies like Electronic Data Systems and Qwest. Investment banker Babcock \& Brown assigned the stock to some London investors who did not have to pay American taxes. Through a series of multilayered leasing arrangements, this gave them deductions worth $\$ 375$ million (Johnston, 2003). Unable to use the deductions, they sold the stock and the deductions to America investors. Everybody was happy except the IRS.

Under a doctrine known as "economic substance," courts have held that if a business transaction has no value except to create tax losses, then it can be disallowed by the IRS (Johnston, 2003). In recent testimony, Dr. Scholes tried to show that the acquisition had economic substance beyond just acquiring tax losses. 


\section{CURRENT ISSUES}

"With Corporate America in low regard, tax shelter abuses could easily turn into the next scandal" (Byrnes, 2003). Many Fortune 500 companies, as well as their officers and directors have been utilizing tax shelter advice provided by their auditors as well as other providers (see Figures $2 \& 3$ ).

Figure 2

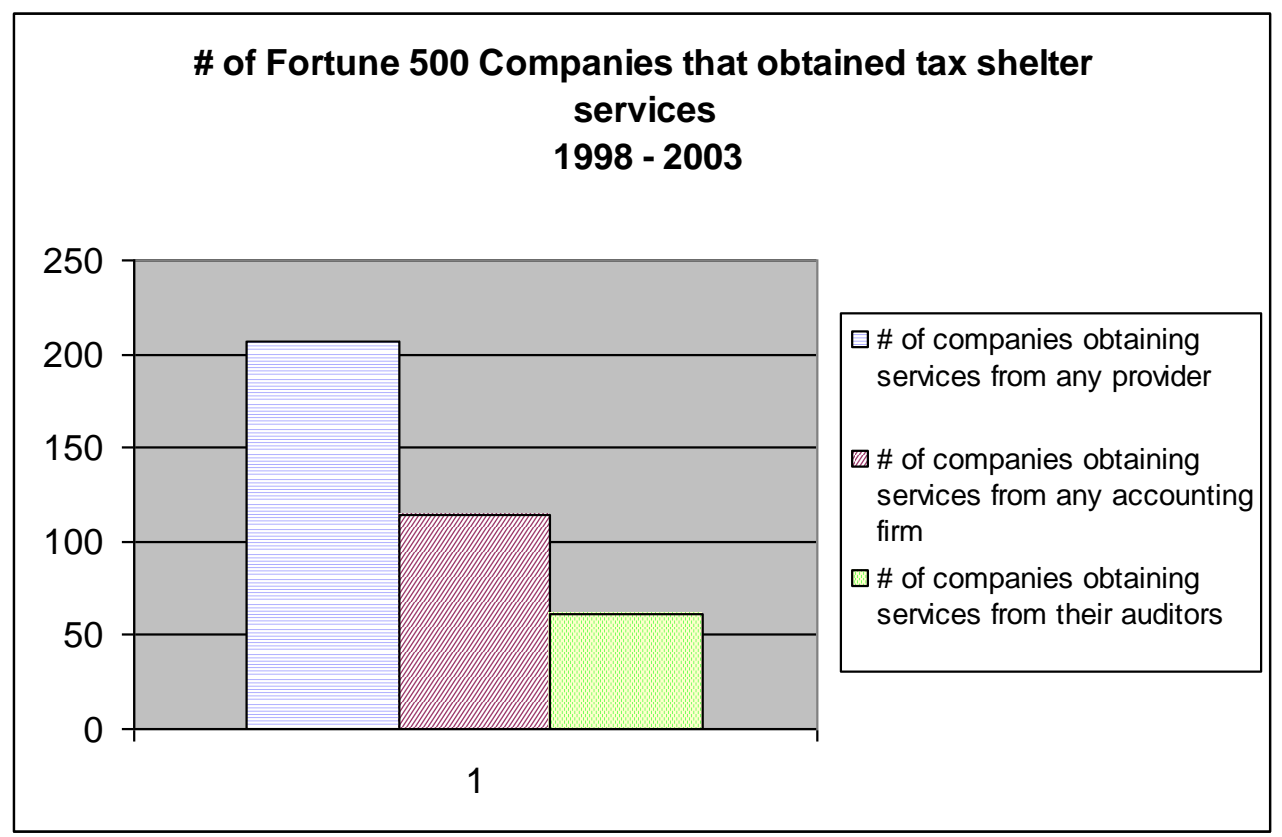

Figure 3

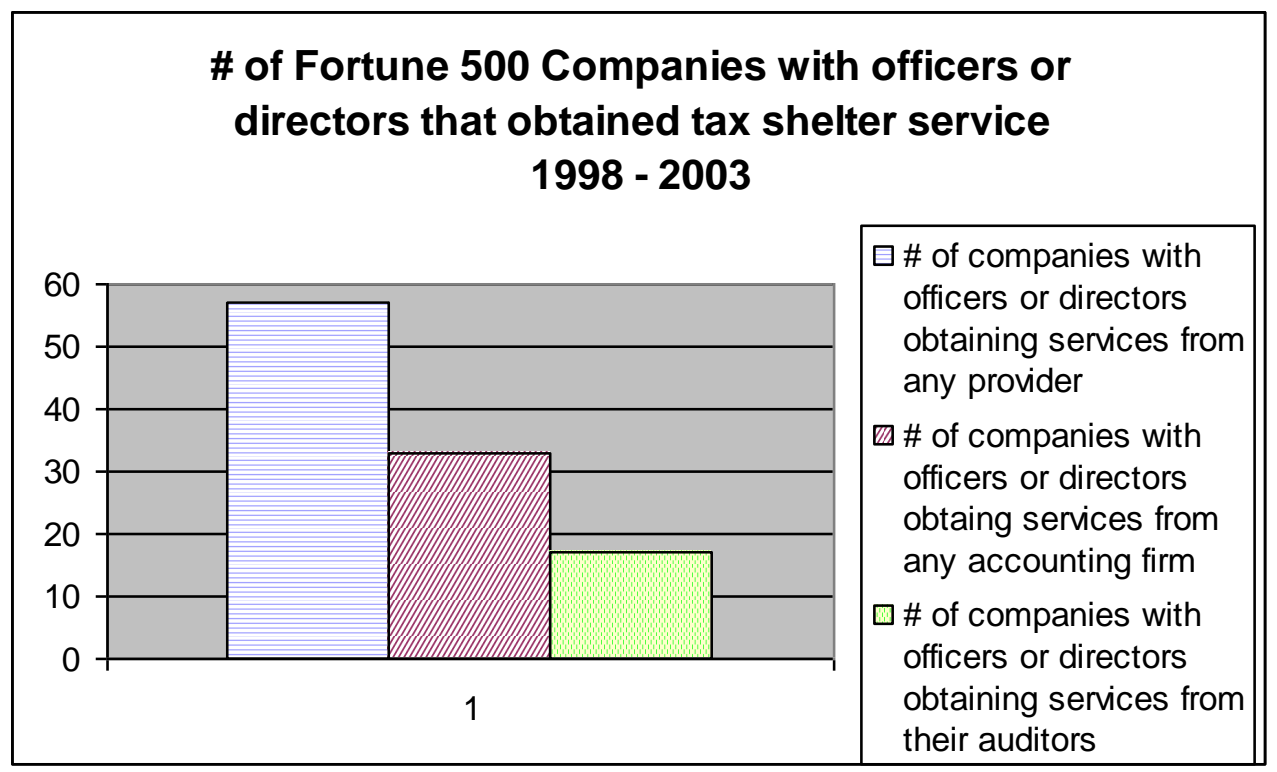


Concerned that the tax planning arm of accounting firms has gotten too close to the top executives of the clients they audit, Congress has asked the SEC to reconsider a decision to let auditors provide tax advice to corporate clients.

For the past two years, the IRS has offered amnesty to taxpayers who reveal questionable tax deductions (Byrnes, 2003). The agency then pushes promoters of those shelters to reveal other clients. The IRS reports that this strategy has uncovered hundreds of abusive shelters.

The IRS conducts promoter examinations in situations where a promoter did not comply with regulations requiring identification of potentially abusive tax avoidance transactions by registering such transactions, and maintaining or making investor lists available to the IRS upon request.

When a transaction has been determined to be abusive, the IRS publishes guidance designed to deter subsequent promotion and investment in the transaction. It also helps to facilitate the identification of investors and other promoters.

\section{Sprint, the Next Corporate Scandal?}

Recently, writers for Fortune and Business Week magazines have suggested that this lucrative trade could become America's next corporate scandal. Revelations in February disclosed that Sprint Corp.'s top two executives attempted to avoid taxes on nearly $\$ 200$ million in stock options. This furor has intensified with new disclosures about Enron's scams (France, 2003). Sprint's top two executives, Chairman and CEO, William T. Esrey, and President, Ronald Lemay left this past year under a shadow of controversy from a risky effort to shelter stock option gains from taxes.

Numerous lawsuits have been filed against Sprint Corp. over its executives' use of tax shelters. These lawsuits allege that Sprint misled investors "by failing to disclose that its earnings were being artificially boosted" by tax shelters (Margolies, 2003). The shelters, recommended by Sprint's auditors, Ernst \& Young, involved complex trades that erased Esrey's and LeMay's stock option profits. The allegations say that Sprint incurred substantial tax benefits coming from taxable gains that Esrey, LeMay and other top Sprint officials incurred when they exercised their options. Sprint allegedly did this by taking the value of the exercised options as federal tax deductions. Sprint defends the legality of the shelter along with their auditors, Ernst \& Young.

The IRS, in a related issue, recently settled a dispute with Ernst \& Young, who agreed to pay $\$ 15$ million for failing to properly register tax shelters and similar transactions or properly maintain lists of people who bought them. "KPMG and BDO Seidman, two firms that have been aggressive sellers of tax shelters, are fighting IRS demands for the names of buyers of the shelters. Earlier, PricewaterhouseCoopers and Merrill Lynch settled similar cases, paying what they described as substantial amounts" (Johnston, 2003).

According to Treasury regulations, promoters, like accounting firms, must disclose to the IRS listed tax shelter transactions ${ }^{1}$ that create sizable losses for tax purposes and the clients that use them. The IRS updates this list as additional abusive tax shelters become known. Registration does not indicate the transactions are tax shelters, only that they have tax effects large enough to review.

\section{IRS ENFORCEMENT}

In an effort to strengthen its anti-tax shelter position, the Internal Revenue Service has set new audit priorities. This strategy focuses on key areas of non-compliance and will aggressively examine promoters of schemes first before attempting to identify participants in tax avoidance transactions.

\footnotetext{
${ }^{1}$ Tax shelters that are determined to be abusive are identified as "listed transactions." Listed transactions require disclosure by participating corporations, individuals, partnerships, and trusts.
} 
The Internal Revenue Service and the Treasury department have developed a strategic approach to stop the proliferation of abusive tax avoidance transactions. John Williams, then chief counsel for the IRS, in a presentation to the Chicago Bar Association (Feb. 2003) outlined the IRS's strategy to stop the growth of abusive tax avoidance transactions. First, measures have been implemented to reduce taxpayers' willingness to invest in abusive tax avoidance transactions by reducing the incentive to "play the audit lottery" (Williams, 2003). These actions include increased disclosure requirements for taxpayers and promoters. It also provides for access to the identity of shelter investors from a variety of sources. These sources include examination of promoter compliance with tax shelter registration and investor list maintenance requirements (Williams, 2003).

Secondly, identifying and analyzing transactions marketed to investors so as to issue early public guidance stating the Treasury's and the IRS' view of the transaction. Such early public guidance gives taxpayers, promoters and the IRS' Compliance functions notice of Treasury and IRS concerns regarding a tax avoidance transaction.

When determined to be an abusive transaction, the IRS and the Treasury publishes guidance as early as possible. This process is designed to deter subsequent promotion and investment and facilitate the identification of investors and promoters. It also ensures consistent treatment of these transactions by agents in the field (Agency Group 01, 2003).

The final part of this strategy is strong enforcement efforts, including summons enforcement by the Department of Justice to obtain information, focused examinations of taxpayers and issues, and targeted litigation to establish that promoted tax benefits are not allowed (Williams, 2003).

\section{CURRENT REGULATIONS}

To assist taxpayers, the Internal Revenue Service has published the following description of tax shelters:

While there is no hard and fast definition of abusive tax shelter arrangements, typically they are promoted by the promise of tax benefits with no meaningful change in the taxpayer's control over or benefit from the taxpayer's income or assets. The promised benefits may include reduction or elimination of income subject to tax; deductions for personal expenses paid by the trust or other entity; depreciation deductions of an owner's personal residence and furnishings; a stepped-up basis for property transferred to the trust or other entity; the reduction or elimination of selfemployment taxes; and the reduction or elimination of gift and estate taxes. These promised benefits are inconsistent with the tax rules (Internal Revenue Service [IRS], 2003). $\S 6111(\mathrm{c}) .^{2}$

Similarly, the IRS has published the following information that describes a corporate tax shelter under IRC

An investment that meets the following two requirements under IRC §6111(c) for registration purposes, regardless of whether it is marketed or customarily designated as a tax shelter:

- $\quad$ The investment is one with respect to which a person could reasonably infer from representations made or to be made in connection with the offering for sale of an interest in the investment that the tax shelter ratio ${ }^{3}$ may be greater than 2 to 1 for any investor at the close of any of the first 5 years ending after the date on which the investment is offered for sale; and

- The investment is one that is required to be registered under a Federal or state law regulating securities, or that is sold under an exemption from registration requiring the filing of a notice with a Federal or state agency regulating the offering or sale of securities, or that is a substantial investment (Dept of the Treasury, 2001).

\footnotetext{
${ }^{2}$ An investment may be considered a tax shelter under section 6111(c), a confidential corporate tax shelter, or both.

${ }^{3}$ The tax shelter ratio is the ratio that the aggregate amount of deductions and $350 \%$ of the credits that are represented as potentially allowable to an investor for all periods up to the close of the year.
} 
To be considered a "confidential corporate tax shelter," an investment must meet each of the following requirements:

- A significant purpose of the structure of the investment is the avoidance or evasion of Federal income tax. To be considered avoidance or evasion of tax, the investment must consist of either of the following:

- Listed transactions. This category includes transactions that are either the same or similar to one of the types of transactions that the IRS has determined to be a tax avoidance transaction identified by notice or regulation.

- Other tax-structured transactions. This area generally includes structured transactions which produce federal income tax benefits and that the organizer reasonably expects to be presented to more than one potential individual in the same or substantially similar form.

- The investment is offered to any potential participant under conditions of confidentiality. To be considered confidential, an offeree's disclosure of the structure is limited in anyway by express or implied understanding of the agreement. The organizer knows or has reason to know that the offeree's use or disclosure of information relating to the structure of the transaction is limited for the benefit of any person other than the offeree.

- $\quad$ Organizers of the tax shelters may receive fees in excess of $\$ 100,000$ (in the aggregate). Substantially similar transactions are treated as part of the same tax shelter and the fees from the transactions must be combined (Dept of the Treasury, 2001).

In February of 2003, the IRS issued final tax shelter regulations as part of its efforts to curtail the use of abusive tax shelters. The new regulations do two things to help uncover potentially abusive tax shelters. First, the regulations require taxpayers engaging in reportable transactions to disclose them on their tax returns. Second, certain advisors that render advice to taxpayers on the consequences of such transactions must maintain lists of participants in those transactions (McDonald, 2003). The following sections present a detailed discussion of the new regulations.

The new regulations require all taxpayers participating in a reportable transaction to attach a disclosure statement (Form 8886 [Appendix]) to their federal income tax returns for the year of the transaction. In general, a taxpayer has participated in a reportable transaction if their return reflects the tax benefits or consequences of the transaction.

The IRS lists six categories of reportable transactions. These categories include: 1) listed transactions, 2) confidential transactions, 3) transactions with contractual protection, 4) loss transactions, 5) transactions with a significance book-tax difference, and 6) transactions involving a brief asset holding period.

\section{Listed Transactions}

These transactions are the same or substantially similar to one of the tax avoidance transactions identified by the IRS as a tax avoidance transaction and identified by notice, regulation, or other form of published guidance.

The term "substantially similar" includes any transaction that is: 1) expected to obtain the same or similar types of federal income tax consequences, and 2) either is factually similar, or is based on the same or similar tax strategy.

Even though legal counsel might provide the taxpayer with a tax opinion, that opinion may not be relevant to the determination of whether the transaction is the same as or substantially similar to another transaction. 


\section{PARTICIPATION}

A taxpayer has "participated in" a listed transaction if the taxpayer's tax return reflects federal income tax consequences or a tax strategy described in published guidance. Additionally, a taxpayer has participated in a listed transaction if the taxpayer knows, or has reason to know, that the tax benefits derived came directly or indirectly from federal income tax consequences or a tax strategy described in published guidance.

\section{Confidential Transactions}

Simply put, "a confidential transaction is a transaction that is offered to a taxpayer under conditions of confidentiality" (Kennard, 2003). To be considered a confidential transaction, the taxpayer's disclosure of the tax treatment or tax structure ${ }^{4}$ of the transaction is limited in some manner. This transaction may be limited by an express or implied understanding, or agreement with, or for the benefit of, any person who makes or provides a statement to the taxpayer. That statement must include the potential federal income tax consequences that may result from the transaction.

\section{OFFERING UNDER CONDITIONS OF CONFIDENTIALITY}

If a transaction meets two requirements, it is considered "offered to the taxpayer under conditions of confidentiality." 1) The taxpayer knows or has reason to know that their use or disclosure of information relating to the tax treatment is limited in any manner, such as where the transaction is claimed to be proprietary or exclusive, for the benefit of any person, other than the taxpayer. 2) Someone who makes or provides a statement to the taxpayer as to the potential federal income tax consequences that may result from the transaction.

\section{EXCEPTIONS AND LIMITATIONS}

First, a transaction is not considered "offered to a taxpayer under conditions of confidentiality" if disclosure of the tax treatment or tax structure is subject to restrictions necessary to comply with securities laws.

Second, a transaction is not considered confidential if the taxpayer is permitted to discuss the tax treatment and tax structure of the transaction in the case of a proposed taxable or tax-free acquisition of historic assets of a corporation, other than an investment company.

Third, the transaction is not considered confidential if the taxpayer is allowed to release the tax treatment and tax structure of the transaction no later than the earlier of the date of the: 1) public announcement of discussions relating to the transaction; 2) public announcement of the transaction; or 3) execution of an agreement to enter into the transaction.

Unless otherwise indicated, a transaction is not considered confidential if every person who makes a statement regarding the federal tax consequences to the taxpayer provides express written authorization allowing the taxpayer to disclose the tax treatment and structure of the transaction. This presumption is only available in cases which written authorization permits the taxpayer to reveal the tax treatment and tax structure of the transaction and is given no later than thirty days after being provided with the income tax consequences of the transaction.

\section{Transactions with Contractual Protection}

These transactions give the taxpayer the right to a full or partial refund of fees if all, or part, of the intended federal income tax consequences from the transactions are not met. Additionally, a transaction for which fees are contingent on the taxpayer's realization of deductions, exclusions from gross income, non-recognition of gain, tax credits, adjustments to the basis of property, and any other consequences that may reduce a taxpayer's federal income tax liability is considered a transaction with contractual protection.

\footnotetext{
${ }^{4}$ Tax structure means any fact that may be relevant to understanding the purported or claimed federal income tax treatment of the transaction.
} 


\section{EXCEPTIONS AND LIMITATIONS}

Two exceptions may apply to the definition of a transaction with contractual protection:

- A transaction is not considered to have contractual protection solely because a party to the transaction has the right to terminate the transaction upon the happening of an event affecting taxation of the parties involved.

- Any refundable or contingent fees are not taken into account if a person makes or provides a statement to the taxpayer as to the potential taxation that may result from a transaction.

\section{LOSS TRANSACTIONS}

Many tax shelters permit a taxpayer to deduct a loss for which the taxpayer is not at risk or does not have an economic effect. A loss transaction is any transaction resulting in the taxpayer claiming a loss under section 165 of the code in the following amounts:

- $\quad \$ 10$ million in any single taxable year or \$20 million in any combination of taxable years for corporations and partnerships whose partners are only corporations,

- $\quad \$ 2$ million in any single taxable year or $\$ 4$ million in any combination of taxable years for individuals, all other partnerships, $\mathrm{S}$ corporations, or trusts,

- $\$ 50,000$ in any single taxable year for individuals and trusts if the loss arises as to foreign currency transactions under section 988. In determining when a transaction results in a loss for the taxpayer over a combination of taxable years, only losses claimed in the taxable year in which the transaction is entered into and the five succeeding taxable years are combined (Kennard, 2003).

\section{Transactions with a Significant Book-Tax Difference}

A transaction with a significant book-tax difference is a transaction in which the amount for federal income tax purposes of any item or items of income, gain, expense, or loss from the transaction differs by more than $\$ 10$ million on a gross basis from the amount of the item or items for book purposes in any taxable year (Kennard, 2003). A member of Congress stated that this $\$ 10$ million book-tax difference disclosure requirement would have flagged Enron's tax avoidance transactions.

For the purposes of book-tax determination, offsetting items are not netted for either federal income tax or book purposes. In addition, to calculate the amount of an item for book purposes, generally accepted accounting principles (GAAP) must be used.

\section{EXCEPTIONS}

If a taxpayer in the ordinary course of business keeps books for financial reporting on a basis other than GAAP and does not maintain GAAP books for any purpose, then the taxpayer may determine the amount of a book item by using the books maintained. This exception holds provided the taxpayers keeps the books on the same basis consistently from year to year.

Final disclosure statement regulations provide that the definition of transactions with a significant book-tax difference does not apply to the following two entities:

- $\quad$ Taxpayers that are reporting companies under the Securities Exchange Act of 1934; or

- $\quad$ Business entities that have $\$ 250$ million or more in gross assets for book purposes at the end of any financial accounting period that ends with the entity's taxable year in which the transaction occurs. 


\section{Transactions Involving a Brief Asset Holding-Period}

A transaction involving a brief asset holding period arises when a taxpayer claims a federal income tax credit exceeding $\$ 250,000$ (including any foreign tax credit) and the underlying asset that gives rise to such credit has been held by the taxpayer for 45 days or less. This transaction permits taking a dollar for dollar offset to federal income tax liability.

\section{Disclosure Statement}

As previously mentioned, taxpayers must file form 8886, "Reportable Transaction Disclosure Statement," for each taxable year in which the taxpayer participates in reportable transactions. In addition, a copy of the disclosure statement must be sent to the Office of Tax Shelter Analysis (OTSA) at the same time that any disclosure statement is filed with the taxpayer's return (Kennard, 2003).

A taxpayer may, on or before the date that disclosure would otherwise be required, submit a request to the IRS for a ruling as to whether a transaction is subject to the disclosure requirements.

\section{Registration of Tax Shelters}

According to IRS regulations, tax shelters under section 6111(c) and confidential corporate tax shelters (under section 6111(d)) must be registered by a tax shelter organizer.

Tax shelter organizers include: a person who participated in the organization of the shelter, a person who participates in management of the shelter when it is not properly registered, and a person who participates in the sale of the shelter at a time when that person knows or has reason to know that the shelter has not been properly organized (Dept of the Treasury, 2001).

Tax shelter registration does not apply to the following investments:

- Sales of residences primarily to persons who are expected to use the residence as their principle place of residence.

- Sales or leases of tangible personal property by the manufacturer of the property to persons who are expected to use the property in their principle active trade or business.

- $\quad$ Sales or leases of tangible personal property by a person in the ordinary course of that person's trade or business, if the purchaser is expected to use the purchased property for either personal use or in their principal active trade or business.

- $\quad$ Performance of services in connection with the recipient's principle active trade or business or for the recipient's personal use.

\section{List Maintenance Requirements}

Each "organizer and seller" of a transaction that is a "potentially abusive tax shelter" must prepare and maintain a list of each participant and upon request must furnish such list to the IRS (Kennard, 2003). This list must include:

- the name and registration number, if any, of the tax shelter,

- $\quad$ the name and address and identifying number of each investor,

- the number of units acquired and the date on which each interest is acquired,

- the amount of money invested by each investor, 
- $\quad$ the name, address and employer identification number of any indirect corporate participant in a confidential corporate tax shelter,

- $\quad$ a detailed description of the tax shelter describing both its structure and intended tax benefits,

- a summary or schedule of the tax benefits that each investor is expected to derive,

- $\quad$ copies of any additional written materials that have been given to potential investors,

- $\quad$ if the interest was not acquired from the person maintaining the list, the name of the person from whom the interest was acquired.

- $\quad$ the name and address of each agent of the person maintaining the list. Each advisor must maintain the list for seven years.

\section{VARIOUS APPLICATIONS OF TAX SHELTERS TODAY}

The term 'tax shelter' has been stretched to include any form of tax avoidance through the use of taxable deductions. The following paragraphs discuss some of the more common methods of tax avoidance. These examples are not intended to be a detailed explanation of how each method works, but rather an overview.

\section{Owning Your Own Business}

An extremely effective tax strategy is to convert personal expenses into legitimate business expenses. To do this an individual must own a business and establish a "profit motive." Under the Internal Revenue Code, a "profit motive" is presumed if the business earns any net income in any three out of five business years. In fact, in the early years, a person could defer an IRS challenge as to the legitimacy of the business by filing Form 5213, Election to Postpone Determination as to Whether the Presumption Applies That an Activity Is Engaged in for Profit.

To qualify as a business deduction, the expense must be: ordinary and necessary, paid or incurred during the taxable year, and connected with the conduct of a trade or business (Schnepper, 2003).

\section{Retirement Plans}

With recent legislation dramatically increasing the contribution limits for 401(k) and other tax qualified retirement plans, individual retirement accounts present alternative tax shelters for many Americans. However, recent studies show that there has been a steady decline in the amount of retirement savings in this country.

For most W-2 workers, the 2002 contribution limit for $401(\mathrm{k})$ plans is $\$ 11,000$ with a $\$ 1,000$ per year increase for each of the next four years starting in 2003. After the annual limits reach $\$ 15,000$, they will then be adjusted for changes in the cost of living (Goldstein, 2003).

In addition, the maximum percentage of an individual's compensation that can be contributed to a $401(\mathrm{k})$ plan has increased from $25 \%$ to $100 \%$.

An individual fifty years or older can contribute an extra $\$ 1,000$ to a 401 (k) without regard to the amount of compensation. Starting in 2003, this amount increases by $\$ 1,000$ per year until 2006 when the amount will reach $\$ 5,000$ a year. The overall limit for employer and employee contributions has increased to $\$ 40,000$ (Goldstein, 2003).

Self-employed taxpayers have an additional advantage in the sense that they are able to decide for themselves at what level they will fund retirement plans. It is even possible, depending on income levels, to establish a retirement plan for your own business even if the taxpayer participates in an employer's plan.

Individual Retirement Accounts (IRA's) offer another option for tax avoidance to those who do not have access to a $401(\mathrm{k})$ plan. Contribution limits have been increased from $\$ 2,000$ to $\$ 3,000$. It remains at $\$ 3,000$ in 2004 as well, but increases to $\$ 4,000$ for tax years 2004 through 2007. In 2008 the limit increases again to $\$ 5,000$. 


\section{Home Ownership}

Deductions for interest and real estate taxes present a strong case for home ownership as a tax shelter. In addition, the increased value realized from the sale of the property remains tax-free as long as the gain is less than $\$ 250,000$ ( $\$ 500,000$ if married filing a joint return) and other requirements are met.

Home mortgage interest incurred to purchase, construct, or substantially improve an owner's first or second residence is deductible up to $\$ 1$ million of total debt secured by either home. "Home" for the purpose of these mortgage interest rules includes about any place that has sleeping quarters, cooking facilities, and a bathroom.

The rules allow interest deductions on both a first and second residence. The second residence may be a vacation home; however, homeowners should be aware that special rules apply when renting a vacation home.

Interest on home equity, secured by the first or second home, can also be deducted up to a total amount of $\$ 100,000$ of home-equity debt regardless of the use of the proceeds. Here, if a car purchase or other consumer debt is incurred through a home-equity loan, the interest becomes deductible (Weil, 2003). However, the use of home-equity debt to purchase or maintain municipal bonds is not deductible.

\section{Like Kind Exchanges}

With the real estate market so strong, like kind or 1031 exchanges have attracted more attention these days. The law allows a taxpayer to roll gains on one investment property into another without incurring a tax bill.

Generally, if you exchange business or investment property solely for business or investment property of a like kind, no gain or loss is recognized under Internal Revenue Code Section 1031. Properties are of like kind if they are of the same nature or character, even if they differ in grade or quality. Personal properties of a like class are like-kind properties. However, livestock of different sexes are not like-kind properties. In addition, personal property used predominantly in the United States and personal property used predominantly outside the United States are not like-kind properties (IRS, 2003).

To qualify, and defer capital gains on the sale of investment property, one must reinvest in another holding of equal or greater value (Garcia, 2002). However, a person cannot swap the home they live in. It's a significant point to keep in mind, especially if a person exchanges a piece of property to buy a vacation home. A vacation home will be disqualified as a like-kind property if it's occupied for more than 14 days a year.

According to IRS rules, a broker or middleman must be used to conduct the transactions on behalf of the taxpayer. Neither the taxpayer's attorney nor accountant can be the middleman. These restrictions have spawned a new industry of qualified intermediaries (QI) who focus on 1031 exchanges.

\section{THE CARE ACT OF 2003}

The CARE Act of 2003 has the potential for further restrictions and penalties concerning tax shelter violations (Mendelson, 2003). These include:

- $\quad$ Severe penalties for nondisclosure of reportable transactions, those between $\$ 50,000$ and $\$ 200,000$,

- Require SEC disclosure of such penalties,

- $\quad$ Modifies existing accuracy related and substantial understatement penalties,

- Extends the statute of limitations for the entire return for failure to disclose a listed transaction,

- Denies deductions for interest paid to the IRS if the understatement is attributable to an undisclosed listed transaction,

- $\quad$ Contains severe limits on the ability to have such penalties waived or rescinded. 
It would also repeal the current tax shelter registration provision in favor of a material advisor disclosure requirement. This act passed the Senate by a vote of 95 to 5. In light of the recent corporate scandals such as Enron and Sprint, this act has been predicted to pass the House as well.

\section{CONCLUSIONS}

The final regulations are quite complex and this paper could not address all areas. As an example, an area uncovered by this paper focuses on determining how to decide which set of regulations a taxpayer must use in preparing their returns. The answer has significance because many transactions would not be reportable under prior regulations, but would be under final regulations (Mendelson, 2003). The new shelter regulations do not attempt to describe every transaction that could be perceived as abusive, but rather they identify various outcomes the IRS will analyze.

IRS regulations allow deductions against income for certain transactions. For individuals, these include expenses connected with a business, interest and real estate taxes connected with home ownership, and contributions to qualified retirement plans. In addition, the gain on sale of certain property may be postponed under certain conditions. These include the sale of an individual's primary residence and like-kind or section 1031 exchanges. These deductions or deferrals, when applied according to the Internal Revenue Code, offer many individuals a way to avoid taxes.

The above listed tax shelters do not fit the needs of corporations and wealthy individuals. In this arena, taxpayers turn to more creative ways to avoid taxes. Much secrecy surrounds the tax shelter game. Corporate partners and individuals must often sign non-disclosure agreements. Such silence has slowed the IRS's progress in identifying abusive transactions.

Taxpayers should note that failure to disclose a reportable transaction could lead to sizeable penalties. Businesses must carefully review their transactions to determine whether any fall within the scope of the Final Regulations. These new regulations impose additional costs of compliance as well as potential costs of penalties.

\section{BIBLIOGRAPHY}

1. Agency Group 01. 2003. Tax Day Reminder: Treasury \& IRS Continue to Crackdown on Abusive Tax Shelters. FDCH Regulatory Intelligence Database.

2. Aspen Publishers Inc. June 2003. Final Tax Shelter Reg's Released. (Tax Procedures). Tax Return Preparer's Letter. v.17. i6. p6 (3).

3. Byrnes, N. 2003. Accounting Hacking Away at Tax Shelters; Executive Dodges Have the IRS and Congress Up in Arms. Business Week. i3821. p. 41.

4. Department of the Treasury Internal Revenue Service. 2001. Instructions for Form 8264, Application for Registration of a Tax Shelter.

5. France, M. 2003. The Rise of the Wall Street Tax Machine; The Shelter Game Has Been Hidden and Lucrative. Could it be the Next Scandal? Business Week. i. 3826. p. 84.

6. Garcia, E. 2002. Shelter Gains with a Swap: With Real Estate Investing Hot, a Tax Cut Strategy Takes Center Stage. Money. v. 31. i. 8. p. 121.

7. Goldstein, R. 2003. New Laws Boon for Contributing to Retirement Plans. San Diego Business Journal. v24. i.19. p. 20 (2).

8. Goold, L. 2003. Shelter from the Storm. Journal of Property Management. vol. 68. Issue 3, p20, 1p.

9. Government Accountability Office. February, 2005. Tax Shelters, Services Provided by External Auditors. GAO-05-171.

10. Hoffman, W., Smith, J., and Willis, E. eds. West Federal Taxation Individual Income Taxes, 2003 Edition. Mason, OH. Thompson - Southwestern. 2003.

11. Internal Revenue Service. Abusive Tax Shelters and Transactions. The Digital Daily.

12. International Tax Review. 2002. IRS Cracks Down on Tax Shelters. (News Analysis). v. 13. no. 9.

13. International Tax Review. 2003. IRS Scrutinizes Tax Shelters (News Analysis). v. 14. no. 3. 
14. Johnston, D. 2003. A Tax Shelter Deconstructed. <http://nytimes.com/2003/07/13/businsess/your money/13TAXX.html>. Accessed July 16, 2003.

15. Johnston, D. 2003. Ernst \& Young to Pay U.S. \$15 Million in Tax Case. The New York Times. p. C1. col. 05 .

16. Kahn, J. 2003. Do Accountants Have a Future? Fortune. v. 147. i. 4. p. 115 (2).

17. Kennard, A. 2003. The 2003 Final Tax Shelter Regulations. Corporate Business Taxation Monthly. Vol. 4 Issue 9, p3, 21p.

18. Margolies, D. 2003. Sprint Faces Two More Lawsuits Over Executive Tax Shelters. Knight-Ridder Tribune Business News. no. 03729595.

19. McDonald, J. and Gensiejewski, G. 2003. Treasury Department Issues Final Tax Shelter Regulations. Pennsylvania CPA Journal. vol. 74. issue 2, p14, 2p.

20. Mendelson, D. L. and Emilian, J. 2003. Tax Shelter Final Regs. Tax Adviser. vol. 34. issue 6. p. 338. 7p.

21. Sachdev, A. 2003. Ernest \& Young LLP to Pay IRS \$15 Million for Violating Tax-Shelter Rules. Knight Ridder/Chicago Tribune Business News.

22. Schnepper, J. The Ultimate Tax Shelter: owning your own business. Accessed July 15, 2003. <http://moneycentral.msn.com/content/taxes/taxshelters/p33572.asp>

23. Weil, J. 2003. Home Sweet Deductible Home: Whether You Own a Large House or an Estate or a Condominium in a High-Rise Building, Your Home is Probably the Last Great Widely Available Tax Shelter. Healthcare Financial Management. v 57. i. 6. p. 68 (2).

24. Welty, T. 2002. IRS Aggressively Challenges Privilege. Tax Advisor. vol. 33. no. 10. pp. 670-672.

25. Williams, Jr., B. J. 2003. Resolving Tax Shelters: By Settlement or Litigation. Speech to the Chicago Bar Association Federal Taxation Committee. Accessed July 21, 2003. < http://www.irs.gov/pub/irs-utl/sheltersfeb25.pdf>. 